\title{
Effects of Monascus-fermented Angelica gigas Nakai on the Contents of Serum Lipid and Tissue Lipid Peroxidation in Alcohol Feeding Rats
}

\author{
Hee-Young Ahn', Kyu-Rim Park', Yu-Ra Kim², Kyoung-Hoon Yoon ${ }^{1}$, Jung-Wook Kim ${ }^{3}$ and Young-Su \\ $\mathrm{Cho}^{4} *$
}

\author{
${ }^{1}$ Department of Medical Biosciences, Graduate School, Dong-A University, Busan 604-714, Korea \\ ${ }^{2}$ Department of Biotechnology, Graduate School, Dong-A University, Busan 604714, Korea \\ ${ }^{3} N M T$, Co, Ltd, Busan 617-736, Korea \\ ${ }^{4}$ Department of Biotechnology, Dong-A University, Busan 604-714, Korea
}

Received October 8, 2013 /Revised October 14, 2013 /Accepted November 20, 2013

\begin{abstract}
The effect of Monascus-fermented Angelica gigas Nakai (AFAG) on the contents of serum lipids and tissue lipid peroxidation was investigated in alcohol feeding rats (Alc group). The serum contents of total lipid and free fatty acid in the alcohol feeding rats were significantly increased, but these increases tended to decrease in the AFAG group. The content of serum triglyceride was also significantly decreased in the AFAG group compared to the other groups. The serum content of totalcholesterol was not significantly different between the normal group and the AFAG group. The content of HDL-cholesterol in serum was slightly increased in the AFAG group compared to the Alc group. The content of thiobarbituric acid reactive substances (TBARS) in the liver, heart, spleen, and testis were significantly increased in the Alc group compared to the normal group, but these increases were significantly decreased in the AFAG group. The content of liver zinc was decreased in the Alc group and it was significantly increased in the AFAG group, which suggested that the lipid peroxidation contents are inversely correlated with the liver zinc content. The hepatic glutathione concentration was significantly decreased in the Alc group, but this content was significantly increased in the AFAG group, and it showed the antioxidant ability of glutathione. These activities were also compared to the standard silymarin drug treatment. Thus, the findings of the present study indicated the significant antioxidant and antihyperlipidemic activity of Monascusfermented Angelica gigas Nakai against ethanol-induced toxicity.
\end{abstract}

Key words : Monascus-fermented Angelica gigas Nakai, thiobarbituric acid reactive substances (TBARS), reduced glutathione (GSH), antihyperlipidemic activity, alcohol

\section{서 론}

최근 복잡한 사회구조로의 변화와 업무로 인한 스트레스를 해소하기 위한 하나의 방편으로 잦은 음주 자리를 갖는 현상 이 늘어나는 추세이다. 이러한 잦은 음주로 인해 알코올에 의 한 인체 건강에 심각한 문제가 제기되면서 건강기능 식품이나 약품 개발의 연구가 활발히 진행되고 있다. 현재까지 임상적 으로 사용되고 있는 대표적인 간 질환 치료제인 silybin 및 silymarin의 경우 국화과 식물인 마리아엉겅퀴(Silybum marianum)의 열매에서 분리되었으며, 차전자(Plantago asiatica)의 aucubin, ursodesoxycholic acid 및 vitamin B군 등이 간 독성

\footnotetext{
*Corresponding author

Tel : +82-51-200-7586, Fax : +82-51-200-7505

E-mail : choys@dau.ac.kr

This is an Open-Access article distributed under the terms of the Creative Commons Attribution Non-Commercial License (http://creativecommons.org/licenses/by-nc/3.0) which permits unrestricted non-commercial use, distribution, and reproduction in any medium, provided the original work is properly cited.
}

치료제로 사용되고 있으나, 이들 질환의 심각성과 빈도수에 비해 개발된 치료제가 많지 않은 실정을 감안하면 천연물에서 의 간 질환 치료제의 개발은 그 의미가 크다고 할 수 있다[24]. Angelica gigas Nakai는 한국이름으로 참당귀로 불리어 지 고 있으며, 아시아 국가에서 전통적으로 한방 의약품으로 사 용 되고 있으며, 미국 및 유럽에서도 여성의 건강 관리를 위한 한약제로 잘 알려져 있다. 국내에서 자생되고 있는 참당귀의 한방 생리적 약효성분으로는 coumarine계의 decursin, decursinol angelate, nodakenetin, nodakenin, umbelliferone, $\beta$ sitosterol, $a$-pinene, limonene 등이 함유되어 있다[13]. Coumarine 유도체 중에서 decursin, decursinol angelate는 가 장 풍부한 구성요소로, antibacterial [18], antiangiogenic [14], antitumor [17] 등의 약리적인 효과가 보고되어 있다.

한편, Monascus purpureus (M. purpureus)는 반자낭균과 (Hemiascomycetaceae)종의 홍국균속(Monascaceae)에 속하 며 황국균에 가까운 균족으로 현재 약 20종, 균주로서 약 70 종 류가 분리 동정되어 있고 균의 종류에 따라 생물활성에 차이 가 있다. M. purpureus 가 생산하는 색소는 균종에 따라 적색소 
인 rubropuntain 및 monascorubin, 황색소인 monascin 및 ankaflavin, 자색소인 rubropunctamine 및 monascorubramine 등으로 분류된다[27].

최근 들어 $M$. purpureus이 생산하는 생리활성 물질 중에 콜레스테롤 생합성 효소인 HMG-CoA reductase 활성을 억제 하는 monacolin K, mevinolin, lovastatin과 같은 스타틴 계열 의 유효성 검증에 관한 연구도 활발히 진행되는 한편[29], 식품 의약품안전청은 높은 콜레스테롤 수치의 개선에 도움이 되는 홍국제품을 건강기능식품의 신규품목으로 지정하게 됨으로 서 시장의 활성화가 기대되고 있다. 홍국의 우수한 생리활성 성분인 monakolin $\mathrm{K}$, mevinolin, $\gamma$-aminobutyric acid (GABA), acethylcholine을 이용한 새로운 건강기능식품 개발에 활용하 려는 연구가 활발하게 이루어지고 있는 가운데 홍국을 소재로 한 건강지향 관련 기능성식품들이 개발되고 있다[15].

발효는 novel polyphenols, flavonoids, 그리고 coumarins 형성과 같은 bioactive 물질의 구조를 변화 시켜 기능향상에 영향을 끼친다[5]. 미생물을 이용한 biotransformation의 가능 성을 가진 물질들은 세포배양, 실험동물의 대사효소 시스템에 의해 새로운 건강보조식품을 개발하는 밑거름이 될 것이다. 이러한 결과를 바탕으로 본 연구는 알코올성 간독성 흰쥐에 대한 $M$. purpureus 발효 참당귀 분말의 혈청 지질 및 조직 과산 화지질 농도에 미치는 영향에 대해 검토하였다.

\section{재료 및 방법}

\section{실험재료 및 발효조건}

Angelica gigas Nakai (A gigas)는 산청 산청한방약초연구소 (산청, 경남, Korea)에 의해 제공되었다. 본 실험에 사용한 $A$. gigas는 뿌리를 깨끗하게 물로 씻은 후 흙과 이물질을 제거하 고 건조시켜 분쇄 후 시료로 사용하였다. M. purpureus KCCM1002는 한국미생물보존센터에서 구입하였다. M. purpureus의 전배양은 PDA agar로부터 spores를 백금이를 이용 하여 glucose $10 \%$, peptone $5 \%, \mathrm{KNO}_{3} 2 \%, \mathrm{NH}_{4} \mathrm{H}_{2} \mathrm{PO}_{4} 2 \%$, $\mathrm{MgSO}_{4} \cdot 7 \mathrm{H}_{2} \mathrm{O} 0.5 \%$ 그리고 $\mathrm{CaCl}_{2} 0.1 \%$ 가 포함되어 있는 500 $\mathrm{ml}$ flask에 접종시켜 배양하였다. 배양은 $30^{\circ} \mathrm{C}$ 에서 72 시간 150 $\mathrm{rpm}$ 의 조건으로 하였다. 전배양 시켜 얻은 배양액을 $A$ gigas 에 $5 \%(\mathrm{v} / \mathrm{w})$ 수준으로 섞은 다음 $30^{\circ} \mathrm{C}$ 에서 12 일간 발효 시켰 다. 이때 발효과정 중에 건조를 막기 위하여 멸균된 증류수를 일정량 뿌려주면서 발효를 진행시켰다.

\section{실험동물, 식이조성 및 사육조건}

실험동물은 5주령의 Sprague-Dawley계 수컷 흰쥐를 (주대 한 바이오링크(충북 음성, 한국)에서 구입하였다. 일주일간 시 판 고형사료를 급여하면서 환경에 적응시킨 후 본 실험에 사 용하였다. 본 실험은 체중이 동일하게 난괴법(randomized complete block design)으로 분류하여 스테인레스 개별케이지 에서 사육실 온도 $\left(22 \pm 2^{\circ} \mathrm{C}\right)$ 와 습도 $(50 \pm 5 \%)$ 및 명암주기(명주 기: 07:00 19:00)가 조절되는 동물 사육실에서 사육하였다. 식 이 조성은 Table 1과 같으며, 정상군 $(\mathrm{N})$, 알코올 투여 대조군 (Alc), 알코올 + 당귀 분말 투여군(AAG), 알코올 $+M$. purpureus 발효 당귀분말 투여군(AFAG)으로 각 군마다 6마리씩 나 누고, 식이와 물은 8 주간 자유섭취시켰다. 양성 대조군 약물은 간질환 치료제로 시판되고 있는 silymarin을 식이 중에 $0.1 \%$ $(\mathrm{w} / \mathrm{w})$ 을 첨가하였다. 사육기간 중 식이 섭취량은 매일 일정한 시간에 측정하고, 체중은 이틀에 한번씩 측정하였다. 동물사육 은 사육 및 실험동물의 사용에 대한 국립 보건 연구소의 지침

Table 1. Compositions of experimental diets

\begin{tabular}{|c|c|c|c|c|c|}
\hline \multirow{2}{*}{ Component } & \multirow{2}{*}{$\mathrm{N}$} & \multicolumn{4}{|c|}{ Ethanol } \\
\hline & & Alc & $\mathrm{AAG}^{1)}$ & $\mathrm{AFAG}^{2)}$ & $\mathrm{ASM}^{3)}$ \\
\hline Casein & 20 & 20 & 20 & 20 & 20 \\
\hline Cornstarch & 15 & 15 & 10 & 10 & 15 \\
\hline Sucrose & 45 & 45 & 45 & 45 & 44.9 \\
\hline Cellulose & 5 & 5 & 5 & 5 & 5 \\
\hline Corn oil & 10 & 10 & 10 & 10 & 10 \\
\hline Mineral mixture ${ }^{4)}$ & 3.5 & 3.5 & 3.5 & 3.5 & 3.5 \\
\hline Vitamin mixture & 1 & 1 & 1 & 1 & 1 \\
\hline Choline bitartrate & 0.2 & 0.2 & 0.2 & 0.2 & 0.2 \\
\hline DL-Methionine & 0.3 & 0.3 & 0.3 & 0.3 & 0.3 \\
\hline Angelica gigas & 0 & 0 & 5 & 0 & 0 \\
\hline Monascus purpureus fermented Angelica gigas & 0 & 0 & 0 & 5 & 0 \\
\hline Silymarin & 0 & 0 & 0 & 0 & 0.1 \\
\hline Tatal $(\%)$ & 100 & 100 & 100 & 100 & 100 \\
\hline
\end{tabular}

${ }^{1)} \mathrm{AAG}: \mathrm{EtOH}+$ Angelica gigas. ${ }^{2)} \mathrm{AFAG}$ : EtOH+Monascus purpureus fermented Angelica gigas

${ }^{3)}$ ASM: EtOH+Silymarin. ${ }^{4)}$ AIN 93 M-MX mineral mix, MP Biomedicals, Illkirch, France

${ }^{5)}$ AIN 93 VX vitamin mix, MP Biomedicals, Illkirch, France 
에 따랐다. 본 연구는 동아대학교 동물실험 윤리심의 위원회 의 승인(승인번호: DIACUC-승인-11-27)을 받아 진행하였다.

\section{동물실험, 시료 채취 및 분석시료 조제}

동물실험은 4 주간 각 군별로 조제사료를 급여하면서 사육 한 후, 실험 최종일 12 시간 이상 절식시킨 후 디에틸에테르로 가볍게 마취시켜 해부하였다. 개복 후 복부 대동맥으로부터 채혈하여 혈액을 채취하고, 약 30 분간 실온에 방치시킨 후 $3,000 \mathrm{rpm}$ 에서 20 분간 원심분리 하여 혈청을 얻어 혈청 효소 분석에 제공하였다. 채혈 후 각 조직을 적출하여 차가운 $0.9 \%$ 생리식염수로 세척하고 여과지로 물기를 제거한 후 무게를 측정하고 분석시료로 제공 하였다.

\section{혈청 지질농도 및 생화학적 지표분석}

혈청 중의 trigylceride, total-cholesterol, HDL-cholesterol, LDL- cholesterol, total lipid, free fatty acid 및 total protein, globulin, albumin농도는 의료전문수탁검사기관인 네오딘의 학연구소(서울, 한국)에 의뢰하여 분석하였다.

\section{각 조직의 분획 조제 및 과산화지질 측정}

각 조직으로부터 homogenate 분획 조제는 조직을 일정량 취해 $250 \mathrm{mM}$ sucrose를 함유한 homogenate 용액을 4 배량 첨가하여 마쇄 균질액을 제조하였다. 분획한 homogenate 생 체막의 과산화지질 함량은 전보의 방법[26]에 준하여 정량 하 였다. 즉, 각 조직 homogenate 분획 용액 $1 \mathrm{ml}$ 에 각각 thiobarbituric acid (TBA) 시약 $2 \mathrm{ml}$ 를 가하여 잘 혼합하고, 수조 상에서 30 분간 가열한 후 실온에서 방냉하여 $3,000 \mathrm{rpm}$ 으로 10 분간 원심분리 한 상등액을 $535 \mathrm{~nm}$ 에서 흡광도를 측정하였 다. 과산화지질 함량은 malondialdehyde를 $\mathrm{nmol} / \mathrm{g}$ 으로 나타 내었다.

\section{미네랄 함량 측정}

각 조직의 미네랄 함량은 A.O.A.C. 분석 방법에 준하여 측 정하였다[1]. 즉, 간 조직 $1 \mathrm{~g}$ 을 각 $550^{\circ} \mathrm{C}$ 회화로에서 3 시간 회화 시킨 후 $6 \mathrm{~N} \mathrm{HCl}$ 에 용해시켜 완전히 산분해시켜 수욕상 에서 산을 완전히 제거하고, 이 건고물에 $3 \mathrm{~N} \mathrm{HCl}$ 를 가하여 Whatman No. 4 여과지로 여과하여 원소 종류에 따라 각각 일정비율로 희석하여 원자흡광 분광광도계(AAnalyst 300,
Perkin Elmer, Norwalk CT, USA)를 이용하여 측정하였다.

\section{Glutathione 함량 측정}

Glutathione 함량은 각 조직의 homogenate 분획 $0.2 \mathrm{ml}$ 에 3차 증류수 $0.3 \mathrm{ml}$ 과 $0.4 \%$ sulfosalicylic acid $0.5 \mathrm{ml}$ 를 가하여 혼합하고 원심분리 시킨 뒤 상등액 $0.3 \mathrm{ml}$ 에 5,5'-dithiobis (2-nitrobenzoic acid) (DTNB) 발색시약을 첨가하여 $412 \mathrm{~nm}$ 흡광도에서 측정하여 glutathione의 표준 검량 곡선에 의해 함량을 산출하였으며 간 조직 $\mathrm{g}$ 당 $\mathrm{mg}$ 으로 표시하였다[4].

\section{통계처리}

실험으로부터 얻어진 결과치는 one-way ANOVA 검정에 의한 평균치와 표준오차 $(m e a n \pm \mathrm{SE})$ 로 표시하였으며, 각 실험 군 간의 유의성 검증은 Duncan's multiple range test로 하였 다[9].

\section{결과 및 고찰}

\section{체중, 식이 및 음료 섭취량 변화}

알코올성 간 독성 유발 흰쥐의 체중 변화에 대하여 당귀 및 발효당귀 분말의 영향을 조사한 결과는 Table 2 와 같다. 4 주간의 체중 증가량이 정상군 $(\mathrm{N})$ 에 비해 알코올을 투여한 모든 실험군에서 많이 증가하지 않은 것으로 보아 알코올에 의해 성장에 영향을 미친 것으로 보여지며, 식이 섭취량과 음 료 섭취량이 동시에 줄어든 것으로 나타났다. 알코올은 소화 흡수 기관인 소장에서 영양소나 식이성분의 흡수를 떨어트려 영향 불균형을 초래함으로서 체중 증가량의 감소를 가져온다 고 하였다[22]. 최종 체중 증가량을 비교해 볼 때 $\mathrm{Alc}$ 군에 비해 $\mathrm{AG}$ 군에서 $4.7 \%$ 감소하였고, $\mathrm{AFAG}$ 군에서 $10.0 \% \mathrm{AFAG}$ 로 더 큰 유의적인 감소차이를 보였다. Guo et al.의 보고에 따르 면, Angelica의 또 다른 종, Angelica sinensis를 의존 복용 방식 으로 3T3-L1에서 adipocytes에 지방 축적을 감소 시키는 효과 를 확인하였고, Angelica gigantis의 뿌리에서 분리한 decursin, decursinol angelate가 mouse의 복막의 대식세포에서 지질 축 적 억제에 영향이 있다는 것을 확인하였다[12]. 한편, 이전 연 구에서는 발효하지 않은 A gigas의 추출액보다 발효된 $A$. gigas 의 추출액에서 marmesin, decursinol 및 decursin함량이 높은 것으로 보고되었다[13].

Table 2. Effects of AAG, AFAG and ASM on the body weight, food intake and water consumption in alcohol feeding rats

\begin{tabular}{lccccc}
\hline Groups & $\mathrm{N}$ & Alc & AAG & AFAG & ASM \\
\hline Weight gain (g) & $220.58 \pm 10.56^{\mathrm{a}}$ & $146.83 \pm 11.54^{\mathrm{b}}$ & $128.50 \pm 16.16^{\mathrm{b}}$ & $108.93 \pm 11.66^{\mathrm{b}}$ & $121.92 \pm 15.05^{\mathrm{b}}$ \\
Food intake (g/day) & $19.89 \pm 0.51^{\mathrm{a}}$ & $13.83 \pm 0.14^{\mathrm{b}}$ & $13.82 \pm 0.65^{\mathrm{b}}$ & $13.85 \pm 0.41^{\mathrm{b}}$ & $13.33 \pm 0.60^{\mathrm{b}}$ \\
Water consumption (ml/day) & $27.38 \pm 0.94^{\mathrm{a}}$ & $18.75 \pm 1.82^{\mathrm{b}}$ & $19.53 \pm 1.94^{\mathrm{b}}$ & $19.04 \pm 1.13^{\mathrm{b}}$ & $19.51 \pm 1.76^{\mathrm{b}}$ \\
\hline
\end{tabular}

Values are mean \pm S.E, $n=6$. Values with different letters are significantly different at $p<0.05$. Abbreviations are the same as Table 1 . 
Table 3. Effects of AAG, AFAG and ASM in the tissues relative weight in alcohol feeding rats

(\% of terminal $\mathrm{BW})$

\begin{tabular}{lccccc}
\hline Groups & $\mathrm{N}$ & Alc & AAG & AFAG & ASM \\
\hline Liver & $2.16 \pm 0.07^{\mathrm{a}}$ & $3.07 \pm 0.14^{\mathrm{b}}$ & $3.04 \pm 0.13^{\mathrm{b}}$ & $3.11 \pm 0.17^{\mathrm{b}}$ & $2.99 \pm 0.20^{\mathrm{b}}$ \\
Kidney & $0.64 \pm 0.01^{\mathrm{a}}$ & $0.67 \pm 0.03^{\mathrm{ac}}$ & $0.70 \pm 0.03^{\mathrm{ac}}$ & $0.79 \pm 0.02^{\mathrm{b}}$ & $0.73 \pm 0.02^{\mathrm{bc}}$ \\
Heart & $0.19 \pm 0.01^{\mathrm{a}}$ & $0.17 \pm 0.01^{\mathrm{a}}$ & $0.19 \pm 0.01^{\mathrm{a}}$ & $0.20 \pm 0.01^{\mathrm{a}}$ & $0.19 \pm 0.01^{\mathrm{a}}$ \\
Spleen & $0.29 \pm 0.01^{\mathrm{a}}$ & $0.32 \pm 0.01^{\mathrm{ab}}$ & $0.32 \pm 0.02^{\mathrm{ab}}$ & $0.33 \pm 0.01^{\mathrm{b}}$ & $0.31 \pm 0.01^{\mathrm{ab}}$ \\
Testis & $0.83 \pm 0.02^{\mathrm{a}}$ & $0.93 \pm 0.04^{\mathrm{ab}}$ & $0.96 \pm 0.05^{\mathrm{b}}$ & $1.03 \pm 0.04^{\mathrm{b}}$ & $0.98 \pm 0.04^{\mathrm{b}}$ \\
Epididymal fat pad (g) & $2.13 \pm 0.16^{\mathrm{a}}$ & $1.60 \pm 0.11^{\mathrm{b}}$ & $1.44 \pm 0.07^{\mathrm{bc}}$ & $1.22 \pm 0.07^{\mathrm{c}}$ & $1.49 \pm 0.08^{\mathrm{bc}}$ \\
Perirenal fat pad (g) & $2.07 \pm 0.12^{\mathrm{a}}$ & $1.54 \pm 0.14^{\mathrm{b}}$ & $1.30 \pm 0.04^{\mathrm{b}}$ & $1.04 \pm 0.06^{\mathrm{c}}$ & $1.39 \pm 0.06^{\mathrm{b}}$ \\
\hline
\end{tabular}

Values are mean \pm S.E, $n=6$. Values with different letters are significantly different at $p<0.05$.

Abbreviations are the same as Table 1.

\section{각 장기의 무게}

각 장기의 체중에 대한 상대적 중량 $\%$ )을 Table 3에 나타내 었다. 유 등[32]의 연구에서 흰쥐에 $10 \%$ 알코올과 홍국 색소 추출물을 식이 급여 하였을때 농도 의존적으로 간 상대 중량 이 증가하는 경향을 나타낸 것으로 보고하였다. 따라서 본 실 험에서도 정상군에 비해 모든 실험군에서 유의적인 차이를 보여 이들 결과와 일치하였다. 신장, 비장, 고환의 상대중량은 각 실험 군 간에 유의적인 차이를 보였고, 심장은 알코올 투여 한 모든 실험군이 정상군 $(\mathrm{N})$ 에 가까운 수치를 보였다. 부고환 주변지방과 신장 주변 지방의 상대 중량은 정상군 $(\mathrm{N})$ 에 비해 알코올 투여 모든 실험군에서 유의적으로 감소하였고, 특히 발효당귀투여군(AFAG)에서 낮은 감소수치를 보였다. 이는 $\mathrm{AFAG}$ 군이 실험동물의 지방 축적 억제에 효과적이라 사료된다.

\section{혈중 총 지질, 유리지방산, 중성지질 농도 변화}

혈중 총 지질 농도는 정상군인 $\mathrm{N}$ 군에 비해 알코올 대조군 인 Alc군이 다른 군에 비해 유의적으로 감소하였다(Table 4). 이는 Lee 등[19]이 만성적인 알코올 섭취는 간의 지방산 합성 을 촉진하여 알코올성지방간을 유발하고 간에서 혈류로 방출 되는 지질의 양을 증가시켜 혈청의 지질 수준을 상승시킨다고 보고한 결과와 유사하며, 본 실험에서 알코올 급여한 흰쥐의 간이 비대해짐에 따라 간 대사 이상으로 혈중 총 지질 농도가 낮은 것으로 사료된다. 한편, 실험군인 $\mathrm{AAG}$ 군, $\mathrm{AFAG}$ 군과 양 성 대조군인 $\mathrm{ASM}$ 군 모두 정상군에 가까운 수치를 나타내었다.

혈중 중성지질 농도는 $\mathrm{N}$ 군에 비해 $\mathrm{Alc}$ 군에서 현저하게 증
가하였고, 알코올 투여로 인해 증가한 혈청 중성지질 함량은 실험식이 투여로 유의적인 감소 차이를 보였으며, 이 중 $\mathrm{AAG}$ 군보다 AFAG군과 $\mathrm{ASM}$ 군에서 더 감소하는 경향을 보였다. 만성 알코올 중독자에 있어서 혈청 중성지방과 총 콜레스테롤 수준이 증가한다는 사실은 알코올 섭취에 따른 유리 지방산의 에스테르화 촉진, 체내의 알코올 대사에 따른 NADH/NAD+ 비율 증가, 알코올 섭취에 따른 간의 chyromicron remnants 대사 또는 분해 기능의 저해, 혈청 중성지방 수준의 생성 증가 와 이용률 감소 등이 지적되고 있다[20]. $\mathrm{Yu}$ 등은 홍국 첨가 식이를 급여한 흰쥐에서 혈청 중성지방 함량은 $2 \%, 4 \%$ Monascus식이군에서 대조군에 비해 모두 유의적으로 감소되 었다고 하였고[33], Cha 등은 홍국발효홍삼분말을 급여한 흰 쥐에서 혈중 중성지질 농도가 대조군에 비해 홍삼분말 투여군 에서는 감소경향을 보였으나 홍국발효홍삼분말 투여군에서 는 유의적인 증가를 나타냈다고[7] 보고하여 서로 상이한 결과 를 나타낸 것으로 보아, 본 실험에서 발효당귀 분말의 투여로 낮아진 혈중 중성지방 농도의 변화는 홍국균과는 큰 관련이 없는 것으로 보인다. 그러나 알코올 대조군 $(\mathrm{Alc})$ 에서 증가한 중성지질 농도가 $\mathrm{AAG}$ 군, $\mathrm{AFAG}$ 군, $\mathrm{ASM}$ 군에서 감소된 것으 로 보아 당귀분말과 양성대조군인 silymarin의 섭취는 혈중 중성지방의 감소에 영향을 미치는 것으로 사료된다. 한편, 혈 청 유리지방산 농도는 N군에 비해 알코올 투여에 의해 유의적 으로 증가하였고 $\mathrm{AFAG}$ 군과 $\mathrm{ASM}$ 군에서는 유의적으로 감소 하였다.

Table 4. Effect of AAG, AFAG, and ASM on the concentration of total lipid, triglycerede and free fatty acid in alcohol feeding rats

\begin{tabular}{cccc}
\hline Groups & Total lipid $(\mathrm{mg} / \mathrm{dl})$ & Triglyceride $(\mathrm{mg} / \mathrm{dl})$ & Free fatty acid $(\mathrm{uEq} / \mathrm{l})$ \\
\hline N & $419.17 \pm 19.03^{\mathrm{a}}$ & $75.50 \pm 9.59^{\mathrm{a}}$ & $1046.67 \pm 106.20^{\mathrm{a}}$ \\
Alc & $255.50 \pm 19.09^{\mathrm{b}}$ & $156.17 \pm 19.95^{\mathrm{b}}$ & $1853.67 \pm 216.26^{\mathrm{b}}$ \\
AAG & $456.67 \pm 57.96^{\mathrm{a}}$ & $112.33 \pm 15.98^{\mathrm{a}}$ & $1685.83 \pm 238.76^{\mathrm{b}}$ \\
AFAG & $477.86 \pm 30.97^{\mathrm{a}}$ & $112.33 \pm 15.98^{\mathrm{a}}$ & $1574.43 \pm 158.22^{\mathrm{ab}}$ \\
ASM & $459.33 \pm 37.00^{\mathrm{a}}$ & $96.00 \pm 13.23^{\mathrm{a}}$ & $1408.17 \pm 168.44^{\mathrm{ab}}$ \\
\hline
\end{tabular}

Values are mean \pm S.E, $n=6$. Values with different letters are significantly different at $p<0.05$. Abbreviations are the same as Table 1 . 

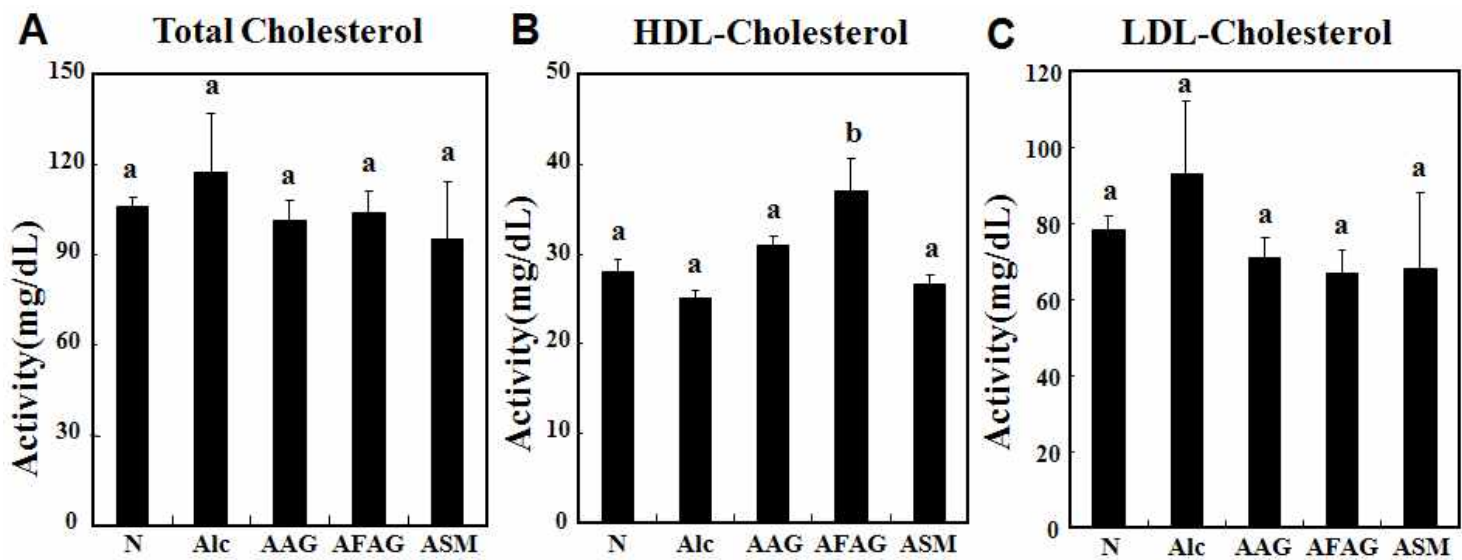

Fig. 1. Effect of AAG, AFAG, and ASM on the concentration of total cholesterol (A), HDL-cholesterol (B) and LDL- cholesterol (C) in alcohol feeding rats. Values are mean \pm S.E, $n=6$. Values with different letters are significantly different at $p<0.05$. Abbreviations are the same as Table 1.

혈중 총 콜레스테롤, $\mathrm{HDL}$-콜레스테롤, $\mathrm{LDL}$-콜레스테롤 농도 변화

혈중 총 콜레스테롤 농도는 $\mathrm{N}$ 군에 비해 $\mathrm{Alc}$ 군에서 $11 \%$ 증 가하였고, 알코올 투여 실험군에서는 N군보다 더 낮은 수준으 로 감소하였지만 각 실험군 간에 통계상의 유의적인 차이는 없었다(Fig. 1).

$\mathrm{HDL}$-콜레스테롤 농도는 $\mathrm{N}$ 군에 비해 Alc군 및 $\mathrm{ASM}$ 군은 감소하였고 $\mathrm{AAG}$ 군은 증가하는 경향은 보였으나 유의적인 차 이는 없었다. 그러나 발효당귀를 식이에 첨가한 AFAG군의 $\mathrm{HDL}$-콜레스테롤 농도은 유의적으로 증가하였다. LDL-콜레 스테롤 농도는 정상군 $(\mathrm{N})$ 에 비해 Alc군에서 유의적으로 증가 하였으나, $\mathrm{Alc}$ 군을 제외한 알코올 투여 군에서는 감소한 경향 을 보였다. 혈청 $\mathrm{HDL}$-콜레스테롤은 소장 및 간세포에서 전구 물질로 합성되어 혈액 내로 들어와 완전한 형태가 되며 체세 포들로부터 콜레스테롤을 간으로 이동시키는 역할을 하는데, 특히 다른 지단백질과는 달리 혈관벽에 침착 되어 있는 LDL콜레스테롤을 분리해내어 간으로 운반하여 에너지로 이용하 거나 체외 배설을 촉진하는 작용을 함으로서 동맥경화 등 심 혈관계 질환의 유발 위험성을 감소시킬 수 있는 유익한 콜레 스테롤로 알려져 있다[28]. Koo 등은 알코올성 간질환 환자들 의 지질 상태를 연구한 결과에서 알코올 중독군의 HDL-콜레 스테롤 함량이 유의하게 낮았다고 보고하였다[16]. 또한 홍국 균이 생산하는 monacolin $\mathrm{K}$, mecivolin 및 lovastatin과 같은 천연 스타틴 계열 약물은 실제로 콜레스테롤 생합성 효소 (HMG-CoA reductase) 활성을 저해하는 작용이 강한 것으로 알려져 있다[30]. 따라서 본 실험에서 당귀분말과 발효당귀 분 말을 급여하였을 때 알코올에 의한 HDL-콜레스테롤 함량을 유의적으로 증가시키고 LDL-콜레스테롤은 유의적으로 감소 시킨 것으로 보아, 홍국균으로 발효시킨 당귀의 섭취는 지속 적인 알코올 섭취로 유발될 수 있는 혈청 지질의 과잉으로 인한 심혈관계 질환을 예방 및 개선하는데 도움이 될 것으로

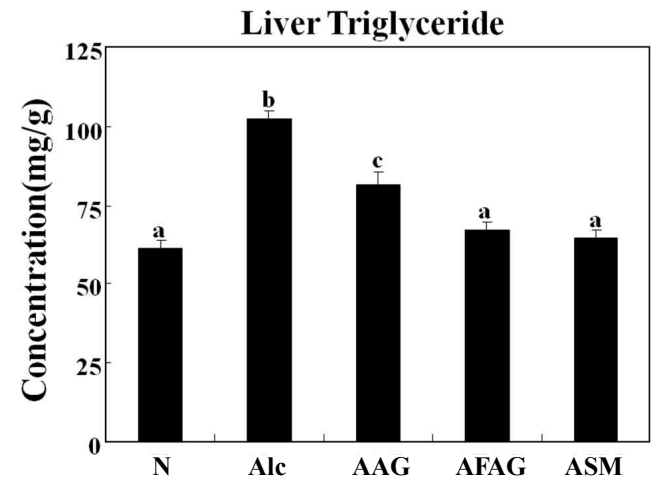

Fig. 2. Effect of AAG, AFAG and ASM on the concentrations of triglyceride in the liver. Values are mean \pm S.E, $n=6$. Values with different letters are significantly different at $p<0.05$. Abbreviations are the same as Table 1 .

사료된다.

간장의 중성 지질 농도

알코올 간독성 실험동물모델에서 실험식이가 간장의 중성 지질 농도에 미치는 영향을 측정한 결과는 Fig. 2와 같다.

각 실험식이군에 따른 간조직의 중성지질 농도는 알코올을 투여한 모든 군에서 N군보다 증가하였으나 실험식이를 투여 한 군에서 모두 유의적으로 감소하였고, $\mathrm{AFAG}$ 군과 $\mathrm{ASM}$ 군은 $\mathrm{N}$ 군과 비슷한 수준으로 감소를 보였다.

알코올성 지방간은 만성적인 에탄올 섭취에 의해 지방산의 합성은 촉진되고 분해는 억제돼 간의 정상세포에 거의 축적되 지 않는 중성지방이 전체 간의 $5 \%$ 이상 축적되어 간의 경도 내지 중정도의 비대를 보이는 것을 말하는데, 이러한 간장 지 질 함량의 증가는 $\mathrm{NAD} / \mathrm{NADH}$ 비율의 불균형으로 인한 영양 소 대사 장애, 지방산 산화 억제에 기인된 것으로 알려져 있다 [10]. Won은 고콜레스테롤 식이와 당귀열수추출물을 급여한 흰쥐에서 간장 중성지방을 포함한 지질 성분이 대조군과 실험 
Table 5. Effect of AAG, AFAG, and ASM on the concentrations of total protein, albumin and globulin in serum of alcohol feeding rats

\begin{tabular}{cccc}
\hline Groups & $\begin{array}{c}\text { Total protein } \\
(\mathrm{g} / \mathrm{dl})\end{array}$ & $\begin{array}{c}\text { Globulin } \\
(\mathrm{g} / \mathrm{dl})\end{array}$ & $\begin{array}{c}\text { Albumin } \\
(\mathrm{g} / \mathrm{dl})\end{array}$ \\
\hline $\mathrm{N}$ & $5.94 \pm 0.07^{\mathrm{a}}$ & $3.48 \pm 0.07^{\mathrm{ab}}$ & $2.43 \pm 0.01^{\mathrm{a}}$ \\
Alc & $5.46 \pm 0.10^{\mathrm{b}}$ & $3.62 \pm 0.03^{\mathrm{a}}$ & $2.39 \pm 0.04^{\mathrm{a}}$ \\
AAG & $5.87 \pm 0.08^{\mathrm{a}}$ & $3.48 \pm 0.12^{\mathrm{ab}}$ & $2.56 \pm 0.02^{\mathrm{b}}$ \\
AFAG & $6.14 \pm 0.18^{\mathrm{a}}$ & $3.35 \pm 0.06^{\mathrm{b}}$ & $2.61 \pm 0.05^{\mathrm{b}}$ \\
ASM & $5.94 \pm 0.08^{\mathrm{a}}$ & $3.24 \pm 0.08^{\mathrm{b}}$ & $2.60 \pm 0.02^{\mathrm{b}}$ \\
\hline
\end{tabular}

Values are mean \pm S.E, $n=6$. Values with different letters are significantly different at $p<0.05$.

Abbreviations are the same as Table 1 .

군간의 유의적인 변화가 없다고 하였으나[31], 본 실험에서는 당귀분말, 발효당귀 분말 및 silymarin 급여가 간장 중성지방 을 감소시키는 효과가 있어 앞의 연구와는 약간의 차이를 나 타내었다.

\section{혈중 단백질, 글로부린, 알부민 농도 변화}

알부민은 간에서 합성되는 혈액 단백질로 혈중 총 단백질의 $60 \%$ 를 차지하고 있으며, 중증 간질환에서 그 농도가 감소되어 중요한 간 질환 기능지표로 이용되고 있다[11]. 또, 글로부린은 혈중의 단백질 중 알부민을 제외한 거의 대부분을 차지하며, 알부민과 반대로 감염증 및 염증성 질환 등에서 증가한다. 혈 중 총 단백질은 $\mathrm{N}$ 군에서 $5.94 \mathrm{~g} / \mathrm{dl}, \mathrm{Alc}$ 군에서 $5.46 \mathrm{~g} / \mathrm{dl}$ 로 $\mathrm{Alc}$ 군에서 함량이 감소되었고, $\mathrm{AAG}$ 군에서 $5.87 \mathrm{~g} / \mathrm{dl}$, $\mathrm{AFAG}$ 군 $6.14 \mathrm{~g} / \mathrm{dl}, \mathrm{ASM}$ 군 $5.94 \mathrm{~g} / \mathrm{dl}$ 로 N군과 비슷한 수치 를 나타내었다(Table 5). 알부민 농도에서 N군과 Alc군은 유 의적인 차이는 보이지 않았지만, $\mathrm{Alc}$ 군이 $\mathrm{N}$ 군보다 낮은 경향 을 나타내었고, $\mathrm{AFAG}$ 군에서 높은 알부민 농도를 보였다. 질 환이 있을 때 증가하는 글로부린 농도는 Alc군에서 높게 나타 났고, $\mathrm{AAG}$ 군은 $\mathrm{N}$ 군과 비슷한 수치를 보였으며, $\mathrm{AFAG}$ 군과 $\mathrm{ASM}$ 군은 $\mathrm{N}$ 군보다 낮은 수치를 나타내었다. 결과적으로, $\mathrm{AAG}$ 군, $\mathrm{AFAG}$ 군에서 간질환 개선효과를 확인하였고, 특히 $\mathrm{AFAG}$ 군에서 알부민 농도는 증가하고, 글로부린 농도는 감소 한 경향을 나타내 $\mathrm{AFAG}$ 는 알코올성 간 손상에 대한 긍정적 인 영향을 미친 것으로 사료된다.

\section{혈청 및 각 조직의 과산화지질 함량}

알코올 간독성 실험모델에 실험식이 급여하였을 때 혈청과 간, 고환, 심장, 신장 및 비장 조직 중의 과산화지질 함량에 미치는 영향은 Fig. 3와 같다.

생체막 지질의 과산화물 생성 정도의 지표로 알려져 있는 TBARS를 측정한 결과, 혈청 및 모든 조직에서 $\mathrm{Alc}$ 군은 $\mathrm{N}$ 군에 비해 유의적으로 증가하였으나, 그 외 알코올 투여 실험군에 서는 감소 수치를 보였다. 간 조직의 homogenate, mitochondria 및 microsome 분획에서 과산화지질 농도는 $\mathrm{AFAG}$ 군과
$\mathrm{ASM}$ 군이 $\mathrm{AAG}$ 군과도 유의적인 차이를 보이며 더 감소하였 고, 혈청 $\mathrm{TBARS}$ 함량은 $\mathrm{AAG}$ 군과 $\mathrm{AFAG}$ 군이 정상군과 비슷 한 수준으로 감소하였으며, 심장, 신장, 고환 및 비장 조직에서 는 알코올 대조군(Alc)을 제외한 알코올 투여군 모두가 정상군 수준으로 감소하였다.

만성적인 알코올 섭취는 활성 산소종을 증가시켜 미토콘드 리아의 단백질을 불활성화하고 미토콘드리아의 구조와 기능 이 저해되는 것으로 보고되었다[3]. 또한 TBARS의 증가는 급 성 또는 만성적인 알코올 투여로 알코올 분해산물인 아세트알 데히드가 다양한 free radical의 생성을 증가시키고 세포질 내 에서xanthine oxidase와 작용하여 superoxidase 생성을 증가 시킴으로써 간 조직이 손상되었기 때문인 것으로 보인다[25]. 따라서 알코올성 간 질환의 원인의 일부가 지질과산화에 의한 것으로 볼 때 이를 방지하기 위해서는 항산화 메커니즘이 필 요하다고 볼 수 있다. 본 실험에서는 발효 당귀 분말을 급여한 $\mathrm{AFAG}$ 군에서 양성대조군 $\mathrm{ASM}$ 군과 비슷한 수준으로 TBARS 함량이 낮아진 결과를 보임으로써 발효 당귀 분말이 혈청 및 조직의 과산화지질 함량을 감소시키는 소재로 사료되며, 정확 한 항산화 메커니즘은 차후에 더 연구되어야 할 것으로 사료 된다.

\section{각 조직의 비헴철 및 아연 농도 변화}

생체에 필수적인 아연은 연조직에 많이 존재하며 특히, 간, 신장 등에서 아연의 축적 및 전환이 일어나 체내 아연의 항상 성 조절에 중요한 역할을 한다[2]. 또한, 철은 체내 과산화수소 를 제거하는 catalase의 구성성분으로 생체 내 과산화지질의 측정에 비헴철 농도 측정은 중요하게 보고되어 있다[23]. Table 6과 같이 간조직에서 아연의 농도는 N군 $0.23 \mathrm{ppm}$, Alc 군 $0.21 \mathrm{ppm}, \mathrm{AAG}$ 군 $0.23 \mathrm{ppm}, \mathrm{AFAG}$ 군 $0.30 \mathrm{ppm}, \mathrm{ASM}$ 군 $0.26 \mathrm{ppm}$ 으로 AFAG군에서 높게 나타났다. 비헴철 함량은 $\mathrm{N}$ 군 $0.86 \mathrm{ppm}$ 이고, Alc군 $1.09 \mathrm{ppm}$, AAG군 $1.07 \mathrm{ppm}$, AFAG 군 $1.05 \mathrm{ppm}, \mathrm{ASM}$ 군 $1.18 \mathrm{ppm}$ 으로 $\mathrm{N}$ 군에 비해 알코올 투여 모든 실험군에서 높은 수치를 보였다. 신장에서 아연농도는 $\mathrm{AAG}$ 군, $\mathrm{AFAG}$ 군, $\mathrm{ASM}$ 군 간의 큰 차이는 없었지만 $\mathrm{Alc}$ 군보 다는 높게 나타났으며, 비헴철에서의 유의적인 차이가 없었 다. 고환에서의 아연과 비헴철의 농도의 변화는 나타나지 않 았다. 혈청에서 아연 농도 또한 간조직과 같이 $\mathrm{AFAG}$ 군이 높 았으며, 이는 양성 대조군인 $\mathrm{ASM}$ 군과 비슷한 수치로 나타났 다. 일반 참당귀가 함유한 아연 농도는 $0.25 \mathrm{ppm}, M$. purpureus 로 발효한 참당귀에 함유된 아연 농도는 $0.37 \mathrm{ppm}$ 으로 농도 차이를 보였으며[6], 위의 아연 농도 수치를 보아 식이에 의해 일부 영향을 받았을 가능성이 있는 것으로 사료된다.

\section{각 조직의 glutathione 농도 변화}

Glutathione은 활성산소종을 직접 제거하고 친전자성 물질 을 무독화시켜 세포의 critical sites를 보호하며, 여러 효소의 
A

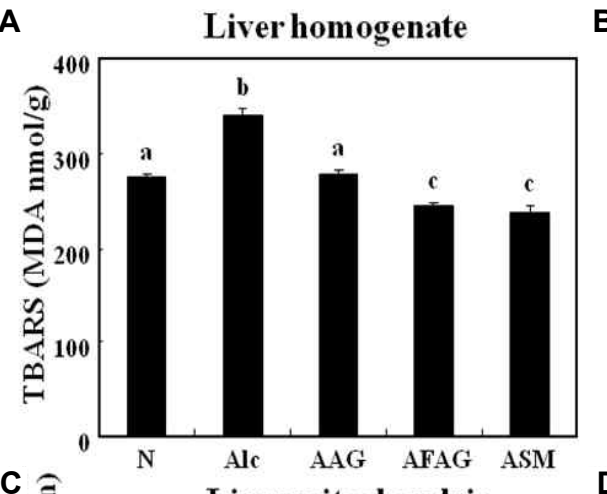

C $\cong$

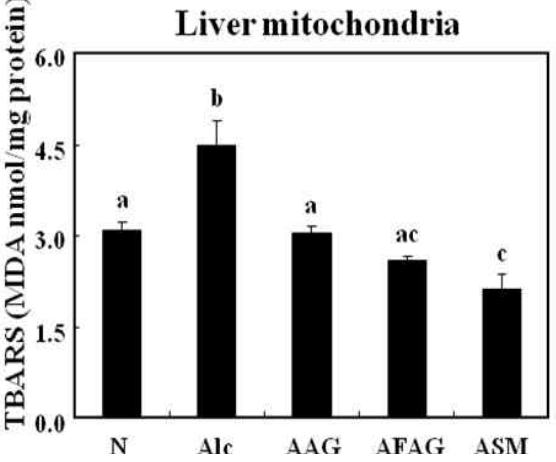

E

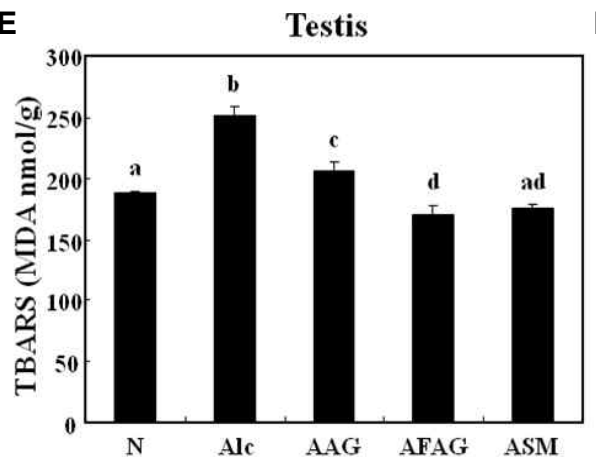

G

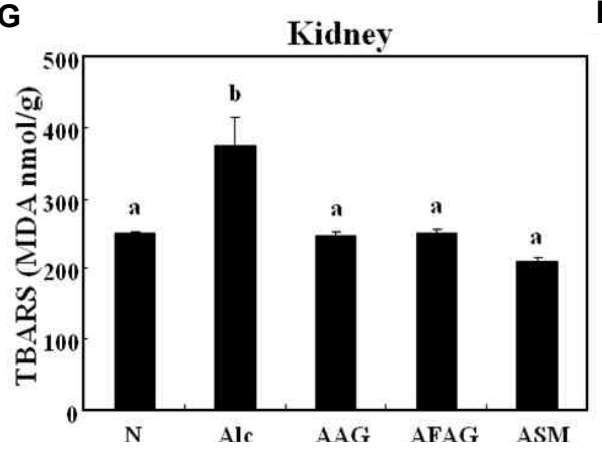

B $\cong$
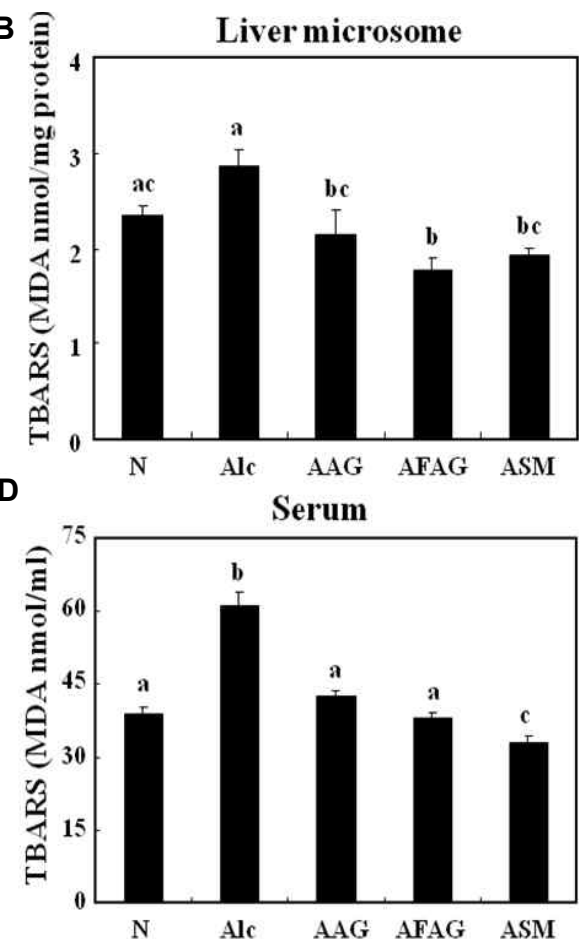

$\mathbf{F}$

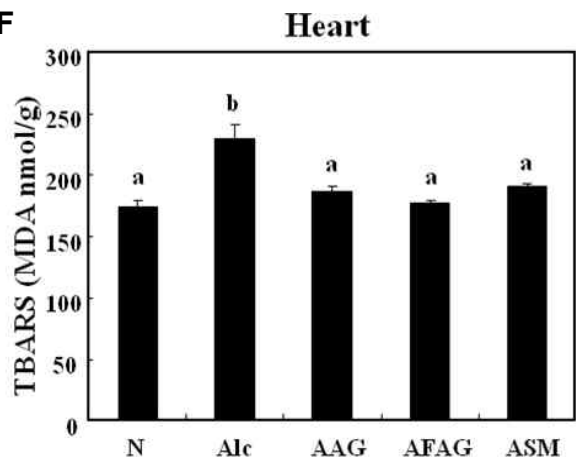

H

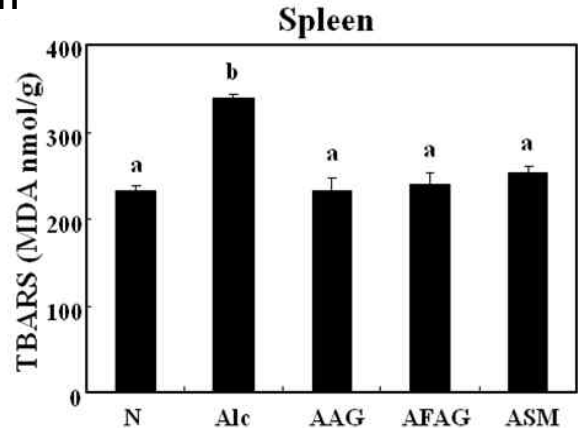

Fig. 3. Effect of AAG, AFAG, and ASM on TBARS (A, B, C, D, E, F, G, H) in alcohol feeding rats. Values are mean \pm S.E, $n=6$. Values with different letters are significantly different at $p<0.05$. Abbreviations are the same as Table 1.

활성조절, prostagalandin $\mathrm{A}$ 와 같은 내인성물질의 합성, 그리 고 $\mathrm{DNA}$ 합성과 면역활성의 조절 등 다양한 생리활성을 가지 고 있어[21], 항산화 방어계에서 중요한 역할을 하는 것으로 잘 알려져 있다. Glutathione 고함유 효모의 급여는 알코올 투여로 인한 간 손상을 어느 정도 개선시키는 것으로 보고[8]
되어, glutathione 농도와 알코올성 간 손상과는 밀접한 관계 가 있다. 간조직의 glutathione 농도를 측정한 결과 알코올 투 여한 실험군 중 Alc군이 낮게 측정되었는데 이는 만성적인 알코올 투여로 인한 손상으로 인해 낮아진 것으로 사료되며, 양성 대조군인 $\mathrm{ASM}$ 군에서 높았으며, $\mathrm{AFAG}$ 는 $\mathrm{ASM}$ 과 거의 
Table 6. Effect of AAG, AFAG and ASM on the nonheme iron and zinc contents in alcohol feeding rats

(ppm)

\begin{tabular}{cccccc}
\hline Groups & $\mathrm{N}$ & Alc & AAG & AFAG & ASM \\
\hline Liver & & & & \\
Zn & $0.23 \pm 0.01^{\mathrm{a}}$ & $0.21 \pm 0.01^{\mathrm{a}}$ & $0.23 \pm 0.01^{\mathrm{a}}$ & $0.30 \pm 0.02^{\mathrm{b}}$ & $0.26 \pm 0.03^{\mathrm{ab}}$ \\
Fe & $0.86 \pm 0.04^{\mathrm{a}}$ & $1.09 \pm 0.06^{\mathrm{b}}$ & $1.07 \pm 0.04^{\mathrm{b}}$ & $1.35 \pm 0.08^{\mathrm{c}}$ & $1.18 \pm 0.07^{\mathrm{bc}}$ \\
Kidney & & & & \\
Zn & $0.16 \pm 0.01^{\mathrm{ab}}$ & $0.15 \pm 0.01^{\mathrm{a}}$ & $0.19 \pm 0.02^{\mathrm{b}}$ & $0.20 \pm 0.01^{\mathrm{b}}$ & $0.19 \pm 0.01^{\mathrm{b}}$ \\
Fe & $0.36 \pm 0.06^{\mathrm{a}}$ & $0.39 \pm 0.01^{\mathrm{a}}$ & $0.41 \pm 0.06^{\mathrm{a}}$ & $0.47 \pm 0.06^{\mathrm{a}}$ & $0.48 \pm 0.03^{\mathrm{a}}$ \\
Testis & & & & \\
Zn & $0.16 \pm 0.01^{\mathrm{a}}$ & $0.16 \pm 0.01^{\mathrm{a}}$ & $0.18 \pm 0.02^{\mathrm{a}}$ & $0.20 \pm 0.01^{\mathrm{a}}$ & $0.21 \pm 0.02^{\mathrm{a}}$ \\
Fe & $0.57 \pm 0.01^{\mathrm{a}}$ & $0.62 \pm 0.04^{\mathrm{a}}$ & $0.63 \pm 0.01^{\mathrm{a}}$ & $0.68 \pm 0.04^{\mathrm{a}}$ & $0.78 \pm 0.04^{\mathrm{b}}$ \\
Serum & & & & \\
Zn & $0.08 \pm 0.01^{\mathrm{a}}$ & $0.13 \pm 0.01^{\mathrm{ac}}$ & $0.18 \pm 0.01^{\mathrm{bc}}$ & $0.23 \pm 0.03^{\mathrm{b}}$ & $0.24 \pm 0.03^{\mathrm{b}}$ \\
Fe & $0.07 \pm 0.01$ & $0.08 \pm 0.01^{\mathrm{a}}$ & $0.07 \pm 0.01^{\mathrm{a}}$ & $0.07 \pm 0.01^{\mathrm{a}}$ & $0.08 \pm 0.01^{\mathrm{a}}$ \\
\hline
\end{tabular}

Values are mean \pm S.E, $n=6$. Values with different letters are significantly different at $p<0.05$.

Abbreviations are the same as Table 1 .
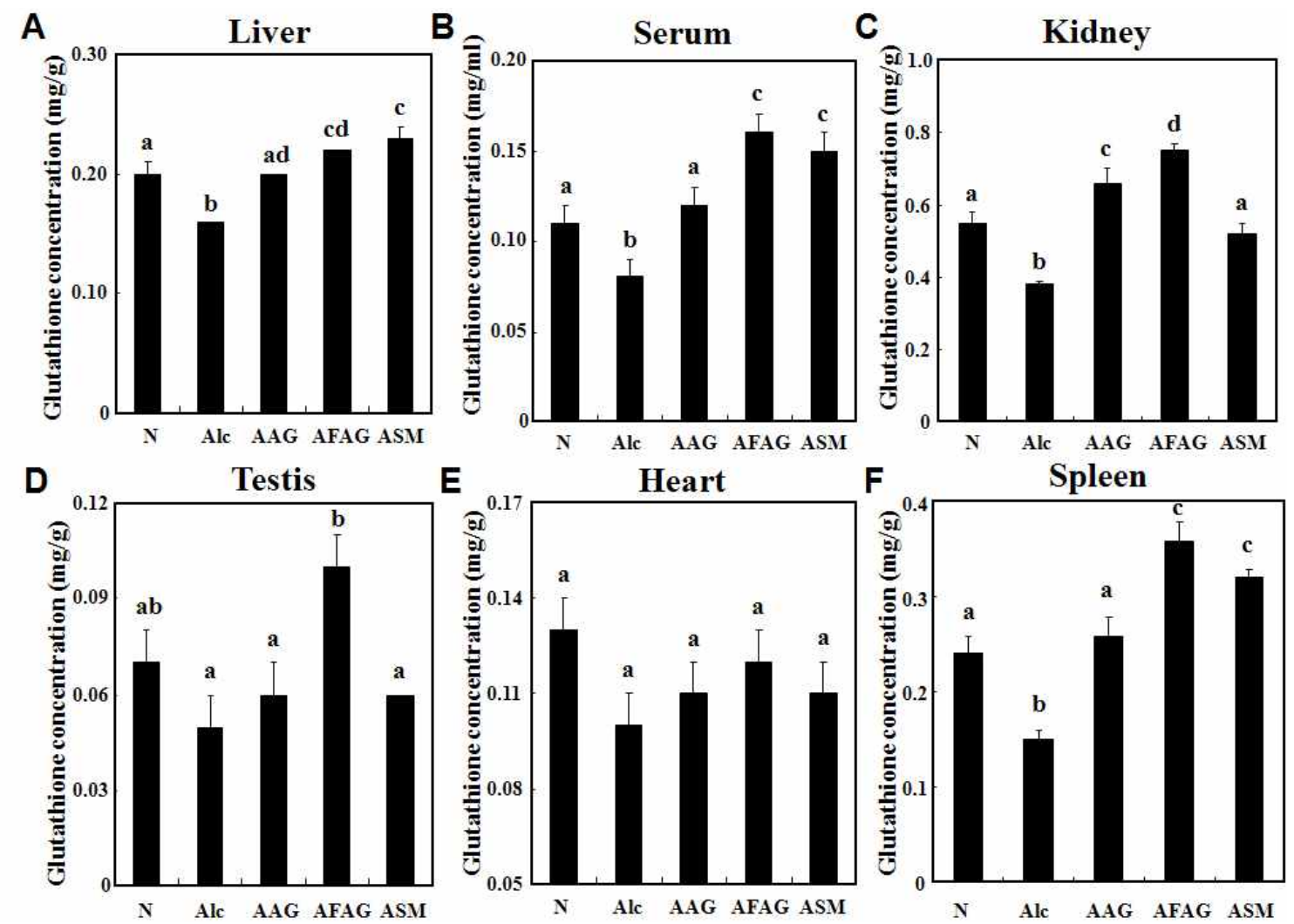

Fig. 4. Effects of AAG, AFAG and ASM on glutathione concentrations (A, B, C, D, E, F) in the tissues of alcohol feeding rats. Values are mean \pm S.E, $n=6$. Values with different letters are significantly different at $p<0.05$. Abbreviations are the same as Table 1.

비슷한 경향으로 확인되었다(Fig. 4). 혈청, 신장, 고환, 비장 조직에서 $\mathrm{Alc}$ 군은 간조직의 결과와 마찬가지로 $\mathrm{N}$ 군보다 $\mathrm{Alc}$ 군에서 glutathione 농도가 낮았고, $\mathrm{AFAG}$ 에서 높은 농도를 나타내었다. 심장에서는 glutathione 농도가 유의한 차이를 나 타내지는 않았지만, AFAG군이 알코올 투여군 중에서는 어느 정도 증가한 경향을 보였다. 특히, 간, 혈청, 신장, 고환, 비장의
대부분의 장기에서 AFAG군의 glutathione 농도가 대체로 높 게 나타나, FAG는 알코올성 간 기능 개선뿐만 아니라 생체 내 조직의 항산화 기능성 소재로써 활용될 수 있을 것으로 사료된다. 


\section{감사의 글}

본 연구는 교육과학기술부의 재원으로 지원을 받아 수행된 산학협력 선도대학(LINC) 육성사업의 연구결과입니다.

\section{References}

1. A.O.A.C. 1975. Official methods of analysis. 12th eds., Association of official analytical chemists. Washington DC, USA.

2. Aggett, P. J. and Comerford, J. G. 1995. Zinc and human health. Nutr Res 53, 16-22.

3. Bailey, S. M. and Cunningham, C. C. 2002. Contribution of mitochondria to oxidative stress associated with alcoholic liver disease. Free Radic Biol Med 32, 11-16.

4. Beutler, E., Duron, O. and Kelly, B. M. 1963. Improved method for the determination of blood glutathione. J Lab Clin Med 61, 882-888.

5. Cha, J. Y., Jun, B. S., Yoo, K. S., Hahm, J. R. and Cho, Y. S. 2006. Fermented Chaga mushroom (Inonotusobliquus) effects on hypolipidemia and hepatoprotection in OtsukaLong-EvansTokushima fatty rats. Food Sci Biotechnol 15, 122-127.

6. Cha, J. Y., Kim, H. W., Heo, J. S., Ahn, H. Y., Eom, K. E., Heo, S. J. and Cho, Y. S. 2010. Ingredients analysis and biological activity of fermented Angelica gigas Nakai by mold. J Life Sci 20, 1385-1393.

7. Cha, J. Y., Park, J. C., Ann, H. Y., Eom, K. E., Park, B. K., Jun, B. S., Lee, C. H. and Cho, Y. S. 2009. Effect of Monascus purpureus-fermented Korean red ginseng powder on the serum lipid levels and antioxidative activity in rats. J Korean Soc Food Sci Nutr 38, 1153-1160.

8. Cha, J. Y., Park, S. H., Heo, J. S. and Cho, Y. S. 2008. Suppressive effect of administrated glutathione-enriched Saccharomyces cerevisiae FF-8 on the oxidative stress in alcoholic fatty liver. J Life Sci 18, 1053-1058.

9. Duncan, D. B. 1957. Multiple range test for correlated and heteroscedastic means. Biometrics 13, 164-176.

10. French, K. T. 1989. Biochemical basis for alcohol-induced liver injury. Clin Biochem 22, 41-49.

11. Friedman, R. B., Anderson, R. E., Entine, S. M. and Hirshberg, S. B. 1980. Effect of disease on clinical laboratory tests. Clinical Chem 26, 1D-476D.

12. Guo, A. J., Choi, R. C., Cheung, A. W., Li, J., Chen, I. X., Dong, T. T., Tsim, K. W. and Lau, B. W. 2009. Stimulation of Apolipoprotein A-IV expression in Caco-2/TC7 enterocytes and reduction of triglyceride formation in 3T3-L1 adipocytes by potential anti-obesity Chinese herbal medicines. Chin Med 4, 5.

13. Heo, J. S., Cha, J. Y., Kim, H. W., Ahn, H. Y., Eom, K. E., Heo, S. J. and Cho, Y. S. 2010. Bioactive meterials and biological activity in the extracts of leaf, stem mixture and root from Angelica gigas Nakai. J Life Sci 20, 750-759.

14. Jung, M. H., Lee, S. H., Ahn, E. M. and Lee, Y. M. 2009.
Decursin and decursinol angelate inhibit VEGF-induced angiogenesis via suppression of the VEGFR-2-signaling pathway. Carcinogenesis 30, 655-661.

15. Kang, D. Z., Um, J. B., Lee, S. K. and Lee, J. H. 2003. Content of rutin and monacoline $\mathrm{K}$ in the red buckwheat fermented with Monascus ruber. Korean J Food Sci Technol 35, 242-245.

16. Koo, B. K., Chung, J. M. and Lee, H. S. 1998. Biochemical evaluation of nutritional status of protein and lipid in patients with alcoholic liver disease. J Korean Soc Food Sci Nutr 27, 1236-1243.

17. Lee, S., Lee, Y. S., Jung, S. H., Shin, K. H., Kim, B. K. and Kang, S. S. 2003. Antitumor activities of decursinol angelate and decursin from Angelic gigas. Arch Pharm Res 26, 717-730.

18. Lee, S., Shin, D. S., Kim, J. S., Oh, K. B. and Kang, S. S. 2003. Antibacterial coumarins from Angelica gigas roots. Arch Pharm Res 26, 449-452.

19. Lee, E. H. and Chyun, J. H. 2009. Effects of Chongkukjang intake on lipid metabolism and liver function in alcoholic fatty liver rats. J Korean Soc Food Sci Nutr 38, 1506-1515.

20. Lieber, C. S. 1993. Aetiology and pathogenesis of alcoholic liver disease. Baillieres Cin Gastroenterol 7, 581-608.

21. Lu, S. C. 2009. Regulation of glutathione synthesis. Mol Aspects Med 30, 42-59.

22. Mendenhall, C. L., Bradford, R. H. and Furman, R. H. 1969. Effects of ethanol on glycerolipid metabolism in rat liver. Biochem Biophys Acta 187, 501-509.

23. Murakami, A., Kishimoto, M., Kawaguchi, M., Matsuura, T. and Ichikawa, T. 1998. Lipid peroxides and their relatives in organs of female rats fed diets containing excessive heme iron. J Korean Soc Food Sci Nutr 51, 9-15.

24. Muriel, P., Garciapina, T., Perez-Alvarez, V. and Mourelle, M. 1992. Silymarin protects against paracetamol-induced lipid peroxidation and liver damage. J Appl Toxicol 12, 439442.

25. Nordmann, R., Ribiere, C. and Rouach, H. 1992. Implication of free radical mechanism in ethanol-induced cellular injury. Free Rad Biol Med 12, 219-240.

26. Ohkawa, H., Ohishi, N. and Yagi, K. 1979. Assay for lipid peroxides in animal tissues by thiobarbituric acid reaction. Anal Biochem 95, 351-358.

27. Pyo, Y. H. and Lee, T. C. 2007. The potential antioxidant capacity and angiotensin I-converting enzyme inhibitory activity of Monascusfermented soybean extracts: evaluation of Monascus-fermented soybean extracts as multifunctional food additives. I Food Sci 72, S218-223.

28. Stephan, A. M. and Wald, N. J. 1990. Trends in individual consumption of dietary fat in the United States 1920-1984. Am J Clin Nutr 52, 457-464.

29. Tsukahara, M., Shinzato, N., Tamaki, Y., Namihira, T. and Matsui, T. 2009. Red yeast rice fermentation by selected Monascus sp. with deep-red color, lovastatin production but no citrinin, and effect of temperature-shift cultivation on lovastatin production. Appl Biochem Biotechnol 158, 476-482.

30. Wei, W., Li, C., Wang, Y. and Kritchevsky, D. 2006. Effect of Monascus purpureusfermented rice on lipidemia and fatty liver in quail. Res Commun Mol Pathol Pharmacol 119, 67-75. 
31. Won, H. R. 2005. Effect of hot water soluble extract from Angelicae Radix on the lipid metabolism and antioxidant defense system. Korean J Community Living Sci 16, 127-132.

32. Yu, T. S., Choi, H. J. and Yoon, C. G. 2003. Effct of Monascus pigment extract on the alcohol metabolism in rats. J Korean
Soc Food Sci Nutr 32, 603-607.

33. Yu, T. S., Kim, H. H. and Yoon, C. G. 2003. Hepatic oxygen free radical metabolizing enzyme activities and serum lipid profile in rats fed diet supplemented with Monascus pigment. J Korean Soc Food Sci Nutr 32, 244-249.

\section{초록 : 알코올성 간독성 흰쥐의 혈청 지질 및 조직 과산화지질 농도에 미치는 발효당귀의 영향}

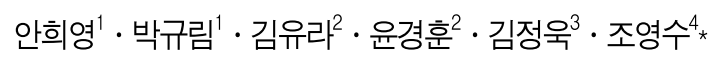

(동아대학교 대학원 의생명과학과, ${ }^{2}$ 동아대학교 대학원 생명공학과, ${ }^{3}$ (주)엔엠티, ${ }^{4}$ 동아대학교 생명공학과)

Monascus purpureus 균주에 의해 발효된 당귀분말을 식이 중에 $5 \%$ 수준으로 첨가하여 $30 \%$ 알코올과 함께 4 주 간 흰쥐에 급여한 후 혈중 지질 농도 및 조직 내 산화 스트레스에 미치는 영향에 대하여 검토하였다. 혈중 중성 지질 농도 및 유리 지방산 농도는 알코올 대조군(Alc)에서의 증가가 알코올 실험군에서 모두 감소하였고, 특히 발효당귀군(AFAG)에서 낮은 감소수치를 보였다. 혈중 총 콜레스테롤 농도는 전반적으로 유의적인 차이는 없었으 나, HDL-cholesterol 농도에서 발효당귀군(AFAG)이 증가수치를 나타내었다. 간장, 심장, 비장,신장, 고환 및 혈청 에서 생체막 과산화지질 생성 정도는 정상군 $(\mathrm{N})$ 에 비해 알코올 대조군(Alc)에서 유의적으로 증가하였고, 이러한 증가는 발효당귀군(AFAG)과 양성 대조군(ASM)에서 정상 수준으로 회복되었다. 간 조직 내 내인성 항산화 물질 인 glutathione 농도는 알코올 대조군(Alc)에서 유의적으로 감소하였고, 발효당귀군(AFAG)에서 유의적으로 증가 하여, 과산화 지질 생성정도와 glutathione 농도는 유의적인 차이가 인정되었다. 이상의 실험결과 발효당귀는 알 코올 투여 동물실험에서 혈중 지질 개선효과는 물론 조직 내 항산화 활성증가로 산화스트레스를 경감시키는 효능 이 있는 것으로 사료되며, 향후 간 독성 개선에 효능을 가지는 건강식품 개발 가능성이 높은 소재로 판단되어 진다. 